\title{
LASER-BEAM WELDING IMPACT ON THE DEFORMATION PROPERTIES OF STAINLESS STEELS WHEN USED FOR AUTOMOTIVE APPLICATIONS
}

\author{
Emil EVIN*, Miroslav TOMÁŚs*; Marek VÝROSTEK*
}

\author{
${ }^{*}$ Faculty of Mechanical Engineering, Department of Automotive Production, Technical University of Košice, Letná 9, 04001 Košice, Slovakia \\ ${ }^{*}$ Faculty of Mechanical Engineering, Department of Computer Support of Technology, \\ Technical University of Košice, Letná 9, 04001 Košice, Slovakia
}

emil.evin@tuke.sk, miroslav.tomas@tuke.sk, marekvyrostek@gmail.com

received 2 November 2015, revised 15 July 2016, accepted 18 July 2016

\begin{abstract}
Materials other than standard and advanced high strength steels are remarkable for the thin-walled structures of the car-body in recent years in order to safety enhancement, weight and emission reduction, corrosion resistance improvement. Thus, there are presented in the paper the deformation properties of laser welded austenitic AISI 304 and ferritic AISI 430 stainless steels compared to these one measured for the high strength low alloyed steel H220PD. The properties were researched by tensile test and 3-point bending test with fixed ends on specimens made of basic material and laser welded one. The specimens were welded by solid state fiber laser YLS-5000 in longitudinal direction (the load direction). The deformation properties such as strength, stiffness and deformation work were evaluated and compared. The strength and stiffness were calculated from tensile test results and the deformation work was calculated from both, tensile test and 3-point bending test results. There has been found only minor effect of laser welding to the deformation properties for high strength low alloyed steel H220PD and austenitic stainless steel AISI 304. Otherwise, the laser welding strongly influenced the deformation work of the ferritic stainless steel AISI 430 as well as the elongation at tensile test.
\end{abstract}

Key words: Stainless Steel, Strength, Stiffness, Deformation Work, Tensile Test, 3-Point Bending

\section{INTRODUCTION}

Car designers are looking for ways to make vehicles lighter and safer to fulfil the emission requirements and secure the passenger's safety. As a result, several new materials such as advanced high strength steels (Baluch, 2014; Mihaliková, 2015; Evin, 2014), magnesium alloys (Solfronk, 2014), plastics and composites (Fuchs, 2008; Jacob, 2004) have been introduced to the industry. Making cars lighter helps increase fuel economy, and making them safer reduces fatalities caused by serious collisions. Stainless steel appears being remarkable as well due to its mechanical properties, energy absorption ability, strength, stiffness, corrosion resistance, formability and weldability.

It is necessary to prevent objects (car components, tree, pole, etc.) from penetrating the cabin in order to secure passengers' survival at collision with another object (Richter, 2005). Thus, the cabin space needs to be perfectly tough and strong. These depend on the strength and deformation characteristics of the carrying car-body structure components. The effectiveness of these components can be improved by design of structure and proper material selection (Bright, 2011; Burdzik, 2012). The structure of the deformation zones components may consist either of several components of different types of steel sheet or of one component consisting of high strength steel or several different high-strength steel sheets with different thickness and strength joined by laser welding - tailored blanks (Schrek, 2014; Merklein, 2014).

Materials used in car body structures have to meet wide range of criteria. The most important criterion for auto-body from the view of safety is the energy absorption ability at impact. For these cases deformation zones are applied in design of auto-body structure. These provide as much as possible energy absorption to secure minimal passenger's space deformation (Burdzik, 2012).

Absorption maximum of kinetic energy in order to reach minimum of crew organism overloading (deceleration) and preserve sufficient strength is the main role of deformable car body elements. Some components such as B-pillar, body sill, front bump$\mathrm{er}$, door beams, etc. have to be strength and stiffer to preserve enough space for passengers survive at side impact. Other car body components such A-pillar, front chassis legs, front wing support, cross-beams, etc. are used to controlled deformation and kinetic energy absorption at frontal impact. Thus, they can be produced from materials with lower strength but very good formability (Burdzik, 2012; Vlk, 2000; Wallentowitz, 1996).

As mentioned, analysis of strength, stiffness and deformation work of materials used for car body components is important. Innovations of materials for car body lie on using such materials whose plastic deformation or mechanically inducted phase transformation is consumed by kinetic energy absorption at car impact. The major importance at frontal impact is on ability of material to absorb the maximum energy, while at lateral impact the main importance is on strength and stiffness due to small deformation zone in door area. (Kramer, 2009; Rediers, 1998, Evin, 2012).

The objective of the paper is to compare selected deformation properties for some stainless steels, when they are potentially used for safety elements, exhaust systems and fuel tanks. These properties have been tested for base and laser-welded material, due to wide application of laser welding when used to prepare the tailored welded blanks in automotive industry. 


\section{MATERIALS AND METHODS}

The laser-beam welding impact on the deformation properties of metal plates from austenitic stainless steel AISI 304 and ferritic stainless steel AISI 430 were researched. The high strength low alloyed steel H220PD has been used as a reference material. The chemical composition shown in Tab. 1 was defined by the mobile spectrometer Belec Compact Port.

Steel strips from metal plates of micro-alloyed steel H220PD, austenitic stainless steel AISI 304 and ferritic steel AISI 430 were welded by laser-beam in continuous welding without protecting gas, using solid-state fiber laser YLS-5000 by IPG laser. Because of the importance of welding parameters (Mei, 2009; Yan, 2010), these have been optimised to reach the best quality of butt weld, based on microscopic structure evaluation in base material, heat affected zone and weld metal (the width of the butt weld and the heat affected zone, hardness HV0.5) as well as macroscopic evaluation of the butt (porosity, weld root fusion). The optimal ones parameters are shown in Tab. 2.

Tab. 2. Laser welding parameters

\begin{tabular}{|l|c|c|c|}
\hline \multicolumn{1}{|c|}{ Material } & $\begin{array}{c}\text { Power } \\
\text { of laser } \\
{[\mathrm{kW}]}\end{array}$ & $\begin{array}{c}\text { Focus } \\
\text { position } \\
{[\mathrm{mm}]}\end{array}$ & $\begin{array}{c}\text { Welding } \\
\text { speed } \\
{\left[\mathrm{mm}^{\left.-\mathbf{s}^{-1}\right]}\right.}\end{array}$ \\
\hline Micro-alloyed steel H220PD & 1.7 & 10 & 50 \\
\hline Austenitic steel AISI 304 & 2.1 & 10 & 70 \\
\hline Ferritic steel AISI 430 & 2.1 & 10 & 70 \\
\hline
\end{tabular}

The mechanical properties such as yield strength, tensile strength, uniform elongation at necking, tensibility, material constant $\mathrm{K}$, strain-hardening exponent of the examined basic materials and laser-welded strips were measured by standardised tests in accordance with STN EN ISO 6892-1, ISO 10113:2006 and ISO 10275:2007 with the sample stated in Fig. 1 and Fig. 2 from load diagrams of the tensile testing machine TIRAtest 2300 measured at the strain rate $\dot{\varepsilon}=\mathrm{d} \varepsilon / \mathrm{dt}=0.0021 \mathrm{~s}^{-1}$. Three specimens have been tested in $90^{\circ}$ to the rolling direction and the average value and standard deviation have been calculated.

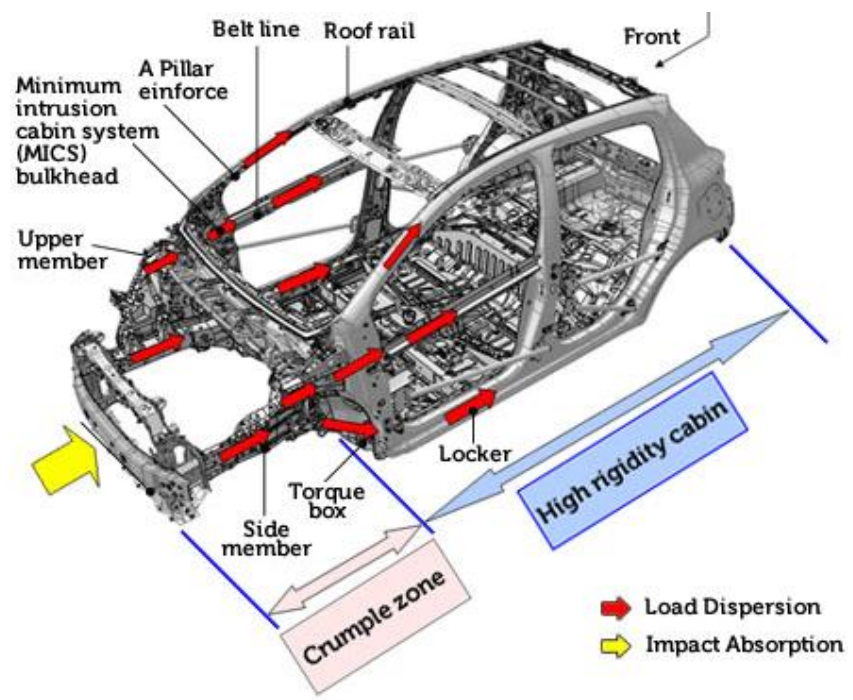

Fig. 1. Impact absorption and load dispersion at side impact (๔) Toyota Innovation)

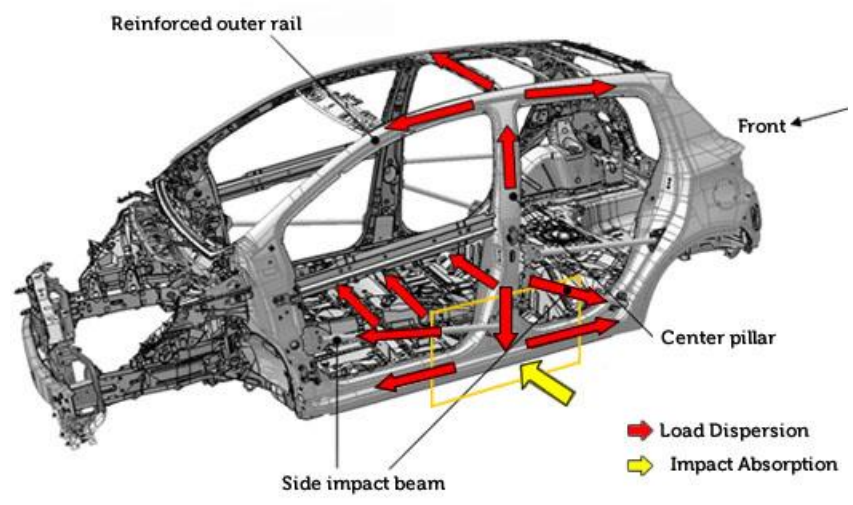

Fig. 2. Impact absorption and load dispersion at frontal impact (๑) Toyota Innovation)

Tab. 1. Chemical composition of materials used

\begin{tabular}{|c|c|c|c|c|c|c|c|c|c|}
\hline Material & & & & Chel & ompos & wt \%] & & & \\
\hline תחמרמו & $C$ & $\mathrm{Si}$ & $\mathrm{Mn}$ & $\mathrm{Cu}$ & $\mathrm{Cr}$ & $\mathrm{Ni}$ & Co & $\mathrm{Nb}$ & $\mathrm{Fe}$ \\
\hline HZLOUD & 0.077 & 0.019 & 0.358 & 0.017 & 0.009 & $<0.002$ & 0.017 & 0.031 & 99.38 \\
\hline$A I C I 201$ & $C$ & $\mathrm{Si}$ & $\mathrm{Mn}$ & $\mathrm{Cu}$ & $\mathrm{Cr}$ & $\mathrm{Ni}$ & Co & $\mathrm{Nb}$ & $\mathrm{Fe}$ \\
\hline AlSI 304 & 0.055 & 0.592 & 1.597 & 0.029 & 18.30 & 7.79 & 0.062 & 0.049 & 71.42 \\
\hline 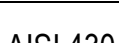 & $C$ & $\mathrm{Si}$ & $\mathrm{Mn}$ & $\mathrm{Cu}$ & $\mathrm{Cr}$ & $\mathrm{Ni}$ & Co & $\mathrm{Nb}$ & $\mathrm{Fe}$ \\
\hline AISI 430 & 0.038 & 0.374 & 0.502 & 0.071 & 16.45 & 0.19 & 0.045 & 0.015 & 82.22 \\
\hline
\end{tabular}

$\mathrm{P}<0.018 ; \mathrm{S}<0.002 ; \mathrm{Ti}<0.007 ; \mathrm{Mo}<0.026 ; \mathrm{Al}<0.026 ; \mathrm{W}<0.036 ; \mathrm{V}<0.049$

The deformation work, i.e. the crashworthiness of experimental materials, has been measured by modified 3-point bending test with fixed ends on the testing machine TIRAtest 2300. Non-standardized specimens - metal steel strips $30 \mathrm{~mm}$ in width and $300 \mathrm{~mm}$ in length - have been made of base material and the laser weld one. The strips were laid at the cylinders of bending fixture and fasten by grips at the ends to prevent the strip pulling out - Fig. 5. The weld was oriented in longitudinal direction in the middle of the strip. The strip has been bent by punch until the strip fracture. The bending force - punch path dependence was recorded by PC during the test. Measured data such as maximum bending force and the punch path were used to calculate the deformation work. The distance of cylinders was $120 \mathrm{~mm}$, the cylinder diameter $30 \mathrm{~mm}$ and the punch velocity $10 \mathrm{~mm} \cdot \mathrm{min}^{-1}$. 


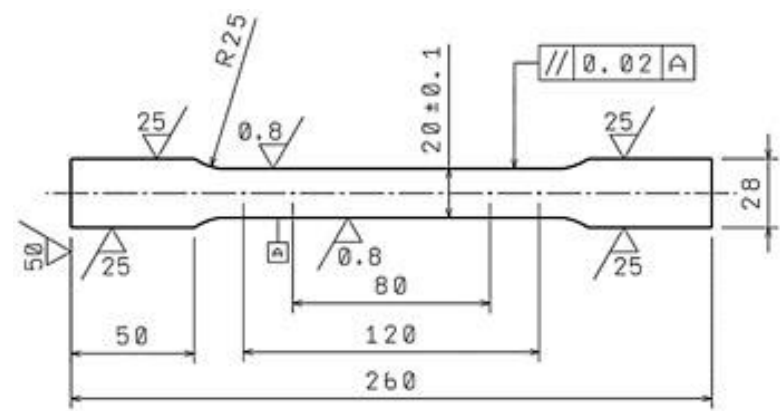

Fig. 3. Standardised specimen for tensile test

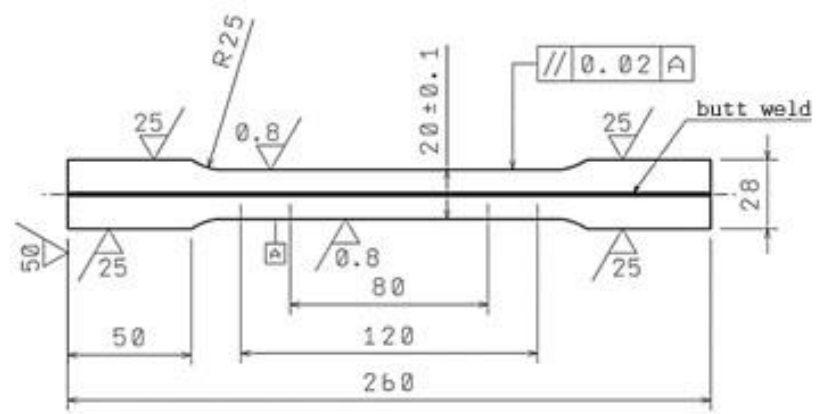

Fig. 4. Laser-welded specimen for tensile test

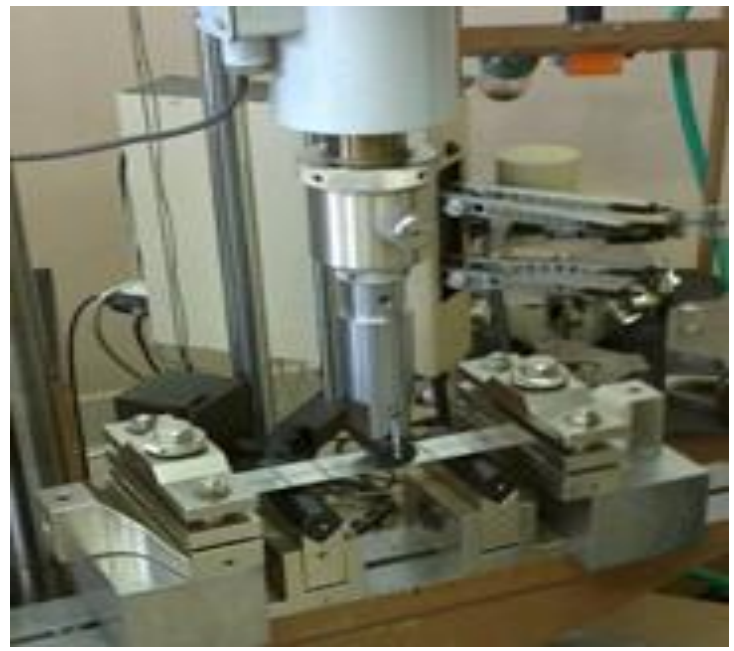

Fig. 5. The bending fixture on the testing machine TIRAtest 2300

\section{REACHED RESULTS AND DISCUSSION}

Measured values of mechanical properties for base material and laser welded ones are shown in Tab 3. These values have been used to calculate the strength, stiffness and deformation work for assessed materials. (Evin, 2012 and 2014)

The strength of a component depends on its geometry and yield stress as follows:

$S T=\frac{R_{P 0.2}}{x}$.

The stiffness is affected by material properties and its geometry as well as follows:

$S T F=V_{0} \frac{\left(R_{P 0.2}\right)^{2}}{x^{2} \cdot E}$

where: $R_{P 0.2}$ - yield stress, $E$ - modulus of elasticity, $x$ - degree of safety or safety constant (1.6 to 2 )

The crashworthiness = absorption ability = deformation work is characteristic currently becoming increasingly important. Recent trends require for a material to absorb more energy in crash scenario. The potential absorption energy can be assessed by the area under the stress-strain curve or load-path. When assessed from the tensile test engineering diagram, the deformation work is calculated from mechanical properties as follows:

$W p l$, necking $=\frac{R_{P 0.2}+R m}{2} \cdot \frac{A g}{100}$,

where: $R m$ - ultimate tensile stress, $A g$ - uniform elongation.

When assessed from load-path curve from 3-point bending test with fixed ends, the deformation work is calculated as follows:

$W p l=\frac{F_{\max } \cdot \Delta l}{2}$,

where: $F_{\max }$ - maximum bending force, $\Delta l$ - punch path to fracture.

The bending force-punch path dependence when 3-point bending with fixed end have been performed is shown in Fig. 6 . The results of calculated values according to eq. (1) to eq. (4) is shown in Tab. 4 for base material and in Tab. 5 for laser-beam welded material.

The graphs for calculated properties before and after welding are shown in Fig. 7 and Fig. 8 when strength and stiffness are compared.

Tab. 3. The properties $\left(90^{\circ}\right.$ to rolling dir.) of base material and laser welded one

\begin{tabular}{|c|c|c|c|c|c|c|c|c|c|c|}
\hline Material & & & $\begin{array}{c}R_{P 0.2} \\
{[\mathrm{MPa}]}\end{array}$ & $\begin{array}{c}\mathrm{Rm} \\
{[\mathrm{MPa}]}\end{array}$ & $\begin{array}{l}\mathrm{Ag} \\
{[\%]}\end{array}$ & $\begin{array}{l}A_{80} \\
{[\%]}\end{array}$ & $\begin{array}{c}\text { At } \\
{[\%]}\end{array}$ & $\begin{array}{c}\mathrm{K} \\
{[\mathrm{MPa}]}\end{array}$ & $\begin{array}{c}r \\
{[-]}\end{array}$ & $\begin{array}{c}\mathbf{n} \\
{[-]}\end{array}$ \\
\hline \multirow{4}{*}{ H220PD } & \multirow{2}{*}{ BM } & average & 380 & 449 & 17 & 29 & 29 & 728 & 0.659 & 0.178 \\
\hline & & stdev & 2 & 1 & 1 & 1 & 1 & 2 & 0.004 & 0 \\
\hline & \multirow{2}{*}{ LW } & average & 366 & 462 & 17 & 26 & 26 & 733 & 0.753 & 0.167 \\
\hline & & stdev & 2 & 2 & 1 & 1 & 1 & 5 & 0.026 & 0 \\
\hline \multirow{4}{*}{ AISI 304} & \multirow{2}{*}{ BM } & average & 302 & 765 & 58 & 62 & 62 & 1594 & 0.931 & 0.462 \\
\hline & & stdev & 1 & 1 & 3 & 2 & 2 & 12 & 0.005 & 0.002 \\
\hline & \multirow{2}{*}{ LW } & average & 304 & 753 & 57 & 62 & 62 & 1563 & 0.958 & 0.451 \\
\hline & & stdev & 3 & 1 & 2 & 1 & 1 & 7 & 0.009 & 0.002 \\
\hline \multirow{4}{*}{ AISI 430} & \multirow{2}{*}{ BM } & average & 300 & 477 & 20 & 30 & 29 & 796 & 0.871 & 0.195 \\
\hline & & stdev & 3 & 4 & 2 & 3 & 3 & 4 & 0.026 & 0.002 \\
\hline & \multirow{2}{*}{ LW } & average & 318 & 437 & 6 & 6 & 6 & 802 & 0.870 & 0.194 \\
\hline & & stdev & 2 & 4 & 0 & 0 & 0 & 15 & 0.020 & 0.006 \\
\hline
\end{tabular}




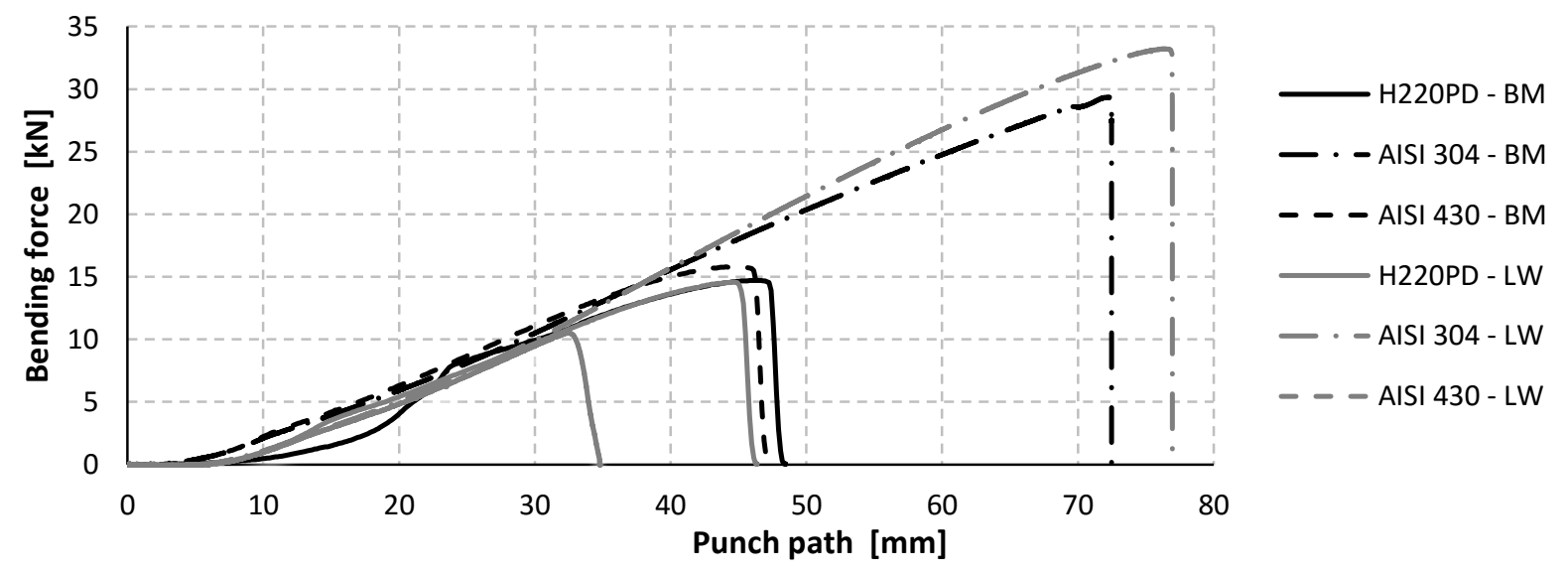

Fig. 6. Bending force - punch path dependence

Tab. 4. Calculated values of safety characteristics - base material

\begin{tabular}{|c|c|c|c|c|}
\hline Material & $\begin{array}{c}\text { Strength } \\
\text { ST }\end{array}$ & $\begin{array}{c}\text { Stiffness } \\
\text { STF }\end{array}$ & $\begin{array}{c}\text { Wpl } \\
\text { eq. (3) }\end{array}$ & $\begin{array}{c}\text { Wpl } \\
\text { eq. (4) }\end{array}$ \\
\hline H220PD & 237.5 & 0.269 & 70.5 & 356.6 \\
\hline AISI 304 & 188.7 & 0.170 & 309.4 & 1063.5 \\
\hline AISI 430 & 187.5 & 0.167 & 77.7 & 374.8 \\
\hline
\end{tabular}

Tab. 5. Calculated values of safety characteristics - laser welded material

\begin{tabular}{|c|c|c|c|c|}
\hline Material & $\begin{array}{c}\text { Strength } \\
\text { ST }\end{array}$ & $\begin{array}{c}\text { Stiffness } \\
\text { STF }\end{array}$ & $\begin{array}{c}\text { Wpl } \\
\text { Eq. (3) }\end{array}$ & $\begin{array}{c}\text { Wpl } \\
\text { Eq. (4) }\end{array}$ \\
\hline H220PD & 228.8 & 0.249 & 70.4 & 337.7 \\
\hline AISI 304 & 190.0 & 0.172 & 301.3 & 1278.5 \\
\hline AISI 430 & 198.7 & 0.188 & 22.7 & 183.1 \\
\hline
\end{tabular}

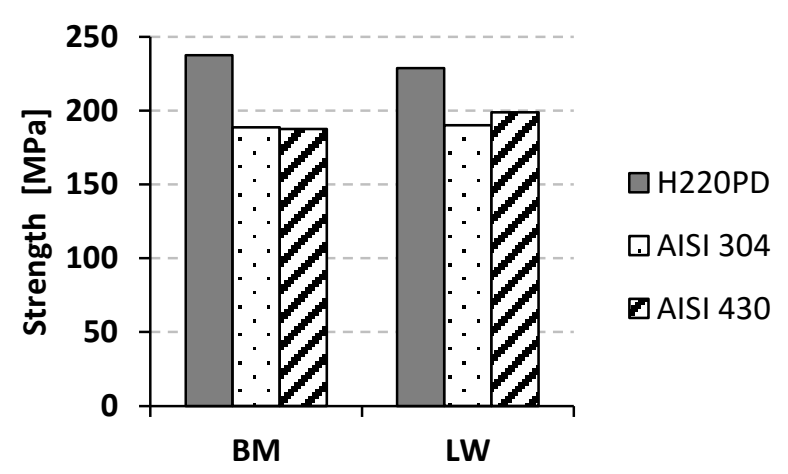

Fig. 7. Strenght comparison

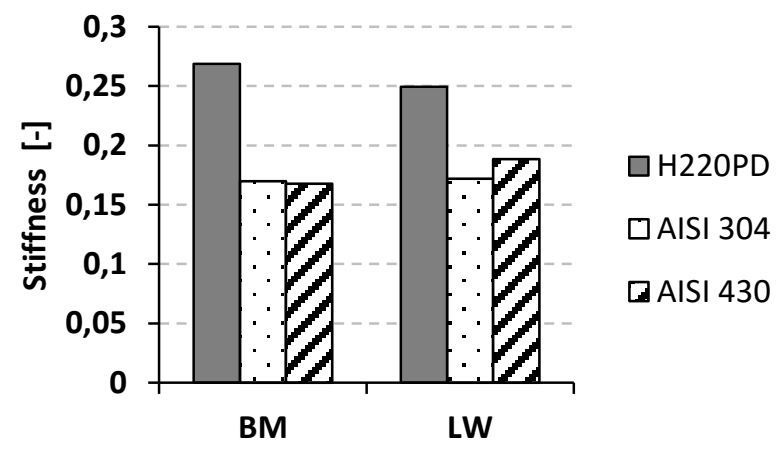

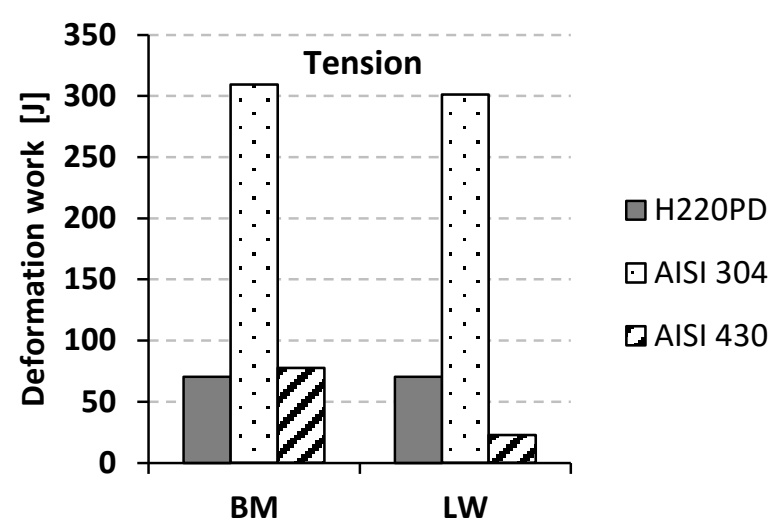

Fig. 9. Deformation work calculated from eq. (3) based on tensile test

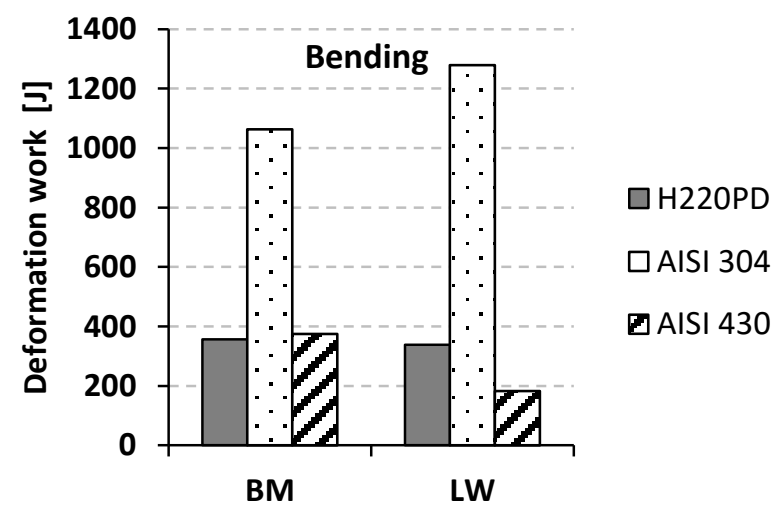

Fig. 10. Deformation work calculated from eq. (4) based on 3-point bending test with fixed ends

Laser welding of austenitic steel AISI 304 has shown only minor influence on strength and stiffness; the stiffness increased about $0.7 \%$ (188.7 to 190) and strength $1.3 \%$ (0.170 to 0.172 ) compared to the base material. The greater influence has been found for ferritic steel AISI 430 when the strength increased about $6.0 \%$ (187.5 to198.7) and stiffness $12.4 \%$ (0.167 to 0.188) compared to the base material. The calculated values for reference material H220PD decreased for strength about $-3.7 \%$ (237.5 to 228.8 ) and stiffness $-7.2 \%$ (0.269 to 0.249$)$ compared to the base material.

Fig. 8. Stiffness comparison 
The graphs for calculated deformation work according to eq. (3), based on tensile test properties and eq. (4), based on the bending force-punch path, are shown on Fig. 9 and Fig. 10. As it is shown in graphs, the laser welding has shown the major influence for ferritic stainless steel AISI 430 when the deformation work decreases about $-70.8 \%$ (77.7 to 22.7$)$ as calculated from tensile test results and $-51.1 \%$ (374.8 to 183.1) as calculated from 3-point bending test results. There is only minor influence of laser welding on the deformation work for austenitic stainless steel AISI 304 (-2.6\% for tensile test and $20.2 \%$ for 3-point bending test). The calculated deformation work for reference material H22OPD decreased about $0.12 \%$ when calculated according to eq. (3) from tensile test results or $5.3 \%$ when calculated according to eq. (4) from 3-point bending test results.

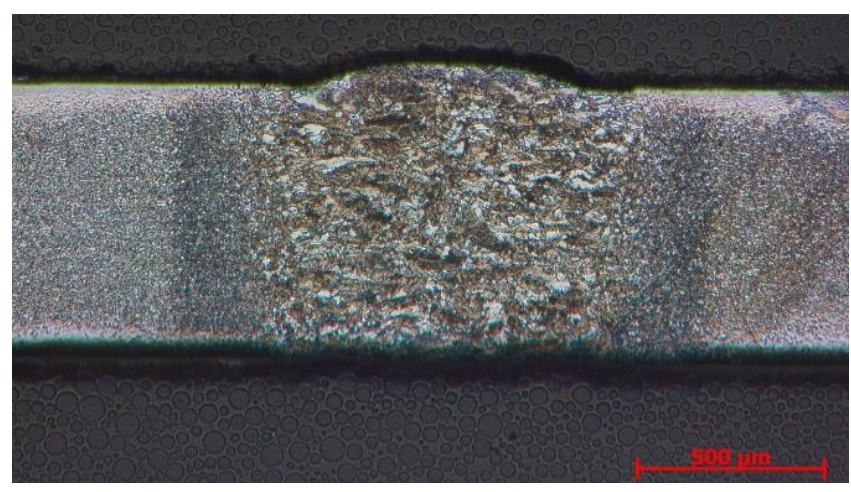

Fig. 11. Macrostructure of laser-beam welded H220PD

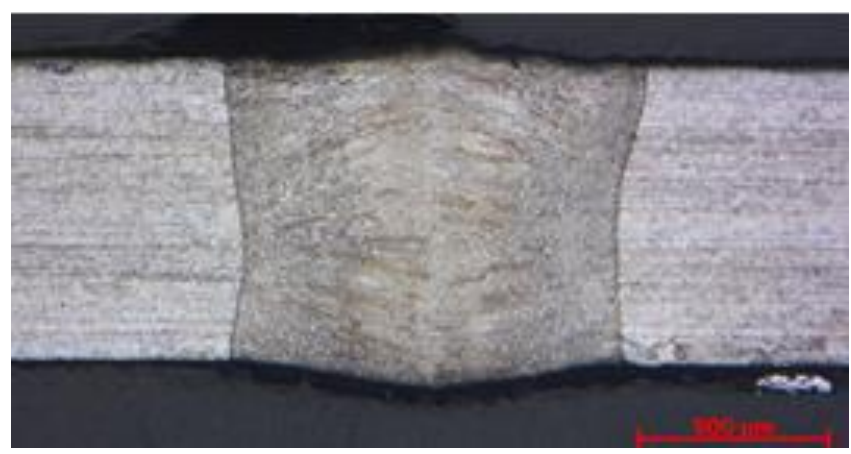

Fig. 12. Macrostructure of laser-beam welded AISI 304

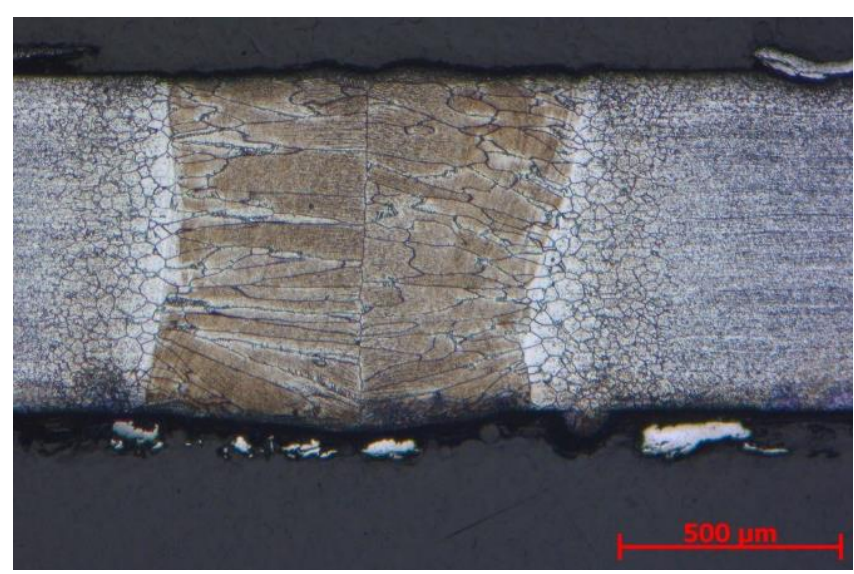

Fig. 13. Macrostructure of laser-beam welded AISI 430

The weld joint of high strength low alloyed steel H220PD when laser-beam welded is shown in Fig. 11. The base material microstructure is fine-grained ferritic with secondary additions of carbides and nitrides. In the weld material hypocutectoid ferrite is created on the grain boundaries of initial austenitic grains. The fine acicular ferrite has been found inside austenitic grains. Some islands of bainitic structure also have been found in the weld metal. The weld metal and heat affected zone is polyedric with the grain size reducing toward the base metal. The results are similar to (Wang, 2015).

The weld joint of austenitic stainless steel AISI 304 when laser-beam welded is shown in Fig. 12. Delta ferrite arranged in rows has been found in the base material microstructure as well as large amount of globulitic carbides. It complies to (Yan, 2010; Hanninen, 2001). The microstructure of weld metal and heat affected zone is austenitic with delta ferrite mainly in the grain boundaries. According to (Yan, 2010), the fast cooling in the laserbeam welding process does not offer sufficient time to complete the phase transformation delta to gamma ferrite. The microstructure is polyedric and the grain size reduces towards the heat affected zone.

Some martensite arranged in rows has been found in the ferritic stainless steel AISI 430 base material structure - Fig. 13 and it complies with (Berretta, 2007). The weld metal microstructure is created by columnar ferrite grains growing from the boundary to the middle. Some martensite has been found in the interdendritic space. The microstructure of heat affected zone is also ferritic with martensite in the grain boundaries.

The results of calculated characteristics of strength, stiffness and deformation work for austenitic stainless steel AISI 304 are comparable to the results for H220PD considering its tendency. There is only minor influence of laser-beam welding to the strength, stiffness and deformation work calculated. It is given by their proper microstructure which is not substantially affected when they are laser-beam welded. There are any improper components in the weld metal influencing the material microstructure after welding; the fine grained ferritic microstructe of H220PD and austenitic with delta ferrite mainly in the grain boundaries for austenitic stainless steel AISI 304. But, there is a major influence of laser-beam welding to the deformation properties of ferritic stainless steel AISI 430, which creates martensite in the interdendritic space of weld metal. The strength and stiffness for ferritic stainless steel AISI 430 improves about $6.0 \%$ and $12.4 \%$, but the deformation work gets worst considerably, i.e. $-70.8 \%$ when calculated from tensile test results according to eq. (3). This result has been confirmed by the deformation work when calculated from 3-point bending test with fixed ends results according to eq. (4); the deformation work gets worse about $-51.1 \%$. Presence of brittle phase structure in the weld metal of ferritic stainless steel AISI 430 has been proven by cracking during the tensile and 3point bending test and crack propagation from the weld metal to the base material.

\section{CONCLUSSION}

The stainless steel use in the automotive industry has shown the wide range of implementations in recent years, such as removable chassis components (bumper beams, frame crossmembers, suspension control arms, subframes), safety/intrusion management components (side impact beams, roof bows, roof rails, B-pillars), entire chassis frame rails, exhaust system components, etc. They present good energy absorption ability when used for safety components. The austenitic grades are applicable when 
laser-beam welding is used at production of tailored welded structures due to preserving its properties, such as strength, stiffness and deformation work, as it has been presented in the paper. Otherwise, the ferritic grades applications are strongly influenced by its microstructure that create embrittling phases after welding.

\section{REFERENCES}

1. Baluch N., Udin Z. M., Abdullah Ch. S. (2014), Advanced High Strength Steel in Auto Industry: an Overview, Engineering, Technology \& Applied Science Research, 4(4), 686-689.

2. Berretta J.R., Rossi W, Neves M.D.M, Almeida, I.A., Junior, N.D.V. (2007), Pulsed Nd:YAG laser welding of AISI 304 to AISI 420 stainless steels, Optics and Lasers in Engineering, 45(9), 960-966.

3. Bright G.W., Kennedy J.I., Robinson F, Evans M. Whittaker M.T., Sullivan J., Gao Y. (2011), Variability in the mechanical properties and processing conditions of a High Strength Low Alloy steel. Procedia Engineering, 10, 106-111.

4. Burdzik R., Folęga P., Konieczny Ł., Łazarz B., Stanik Z., Warczek J. (2012), Analysis of material deformation work measures in determination of a vehicle's collision speed, Archives of Materials Science and Engineering, 58-1, 13-21.

5. Čada R. (2003), Evaluation of strain and material flow in sheet-metal forming, Journal of Mat. Processing Technology,138(1-3), 170-175.

6. Evin E., Tomáš M., Kmec J., Németh S., Katalinic B., Wessely E. (2014), The Deformation Properties of High Strength Steel Sheets for Auto-Body Components, Procedia Engineering, 69, 758-767.

7. Evin E., Tomáš M. (2012), Comparison of deformation properties of steel sheets for car body parts. Procedia Eng., 48, 115-122.

8. Fuchs E.R.H., Field D.R., Roth, R., Kirchain, R.E. (2008), Strategic materials selection in the automobile body. Economic opportunities for polymer composite design, Composites science and technology, 68, 1989-2002.

9. Hanninen H., Romu J., Ilola R., Tervo J., Laitinen A. (2001), Effects of processing and manufacturing of high nitrogen-containing stainless steels on their mechanical, corrosion and wear properties. Journal of Mat. Processing Technology, 117(3), 424-430

10. Jacob G.C., Fellers J.F., Simunovic S., Starbuck J.M. (2004), Energy Absorption in Polymer Composites for Automotive Crashworthiness, Journal of Composite Materials, 36, 813.

11. Kramer F. (2009), Passive Safety of Vehicles, Vieweg+Teubner, Weisbaden. (in German)
12. Mei L., Chen G., Jin X., Zhang Y., Wu Q. (2009) Research on laser welding of high-strength galvanized automobile steel sheets, Optics and Lasers in Engineering, 47(11), 1117-1124

13. Merklein M., Johannes M., Lechner M., Kuppert A. (2014), Review on tailored blanks-Production, applications and evaluation, Journal of Materials Processing Technology, 214(2), 151-164

14. Mihaliková M., Német M., Girman V. (2015), DP 600 steel research of dynamic testing, Metalurgija, 54(1), 211-213.

15. Rediers B., Yang B., Juneja V. (1998), Static and dynamic stiffness - one test both results, Proc. of the 16th IMAC, 30-35.

16. Richter M., Pape H.Ch., Otte D., Krettek Ch. (2005) Improvements in passive car safety led to decreased injury severity - a comparison between the 1970s and 1990s, Injury, 36(4), 484-488.

17. Schrek A., Činák M., Švec P., Kostka P., Gajdošová V. (2014), Influence of Stress-strain Characteristic of Laser Weld Join on the Total Formability of Tailored Welded Blanks, Hutnicke listy, 67(4), 41-44 (in Slovak).

18. Solfronk P., Sobotka J., Kolnerová M., Zuzánek L. (2014), Influence of temperature on formability of magnesium alloy AZ31B. 23rd Int. Conf. METAL 2014, Brno, Czech Republic, 1045-1050.

19. VIk F. (2000), Auto-body of vehicles, Editing and publishing company Vlk, Brno.

20. Wallentowitz H., Adam H. (1996), Predicting the crashworthiness of vehicle structures made by lightweight design materials and innovative joining methods, International Journal of Crashworthiness, 1(2), 163-180.

21. Wang X.N., Chen CH.J., Wang H.S., Zhang S.H., Zhang M., Luo X. (2015), Microstructure formation and precipitation in laser welding of microalloyed C-Mn steel, Journal of Materials Processing Technology, 226(12), 106-114

22. Yan J., Gao M., Zeng X. (2010), Study on microstructure and mechanical properties of 304 stainless steel joints by TIG, laser and laser-TIG hybrid welding, Optics and Lasers in Engineering, 48(4), 512-517

The work has been accomplished under the grant project VEGA 2/0113/16 "Influence of laser welding parameters on structure and properties of welded joints of advanced steels for the automotive industry" and project APVV-0273-12 "Supporting innovations of autobody components from the steel sheet blanks oriented to the safety, the ecology and the car weight reduction". 